\title{
Recovery of villous architecture in gluten enteropathy exacerbated by gastro-jejunal anastomosis
}

\author{
D. G. WEIR \\ M.D., M.R.C.P.I. \\ Lecturer in Clinical Medicine \\ Department of Clinical Medicine, Trinity College, Dublin, and \\ the Federated Dublin Voluntary Hospitals
}

\section{Summary}

Two patients are described whose clinical condition deteriorated following gastric surgery for peptic ulceration. Both were demonstrated to be suffering from gluten enteropathy with generalized malabsorption which included lactose.

Following treatment with a gluten-free diet over a 2-year period the jejunal mucosa showed a marked improvement of villous architecture associated with a return of lactose absorption to normal in one patient. This supports the view that following a gastro-jejunal anastomosis the gastric secretion is not itself injurious to the jejunal mucosal structure.

\section{Introduction}

The jejunal mucosal pattern following partial gastrectomy usually shows either a normal histological pattern or mild inflammatory changes (Baird \& Dodge, 1957 ; Lees \& Grandjean, 1958 ; Shiner, 1959 ; Weir, Temperley \& Gatenby, 1963 ; Scott, Williams \& Clarke, 1964). Other workers (Paulley, Fairweather \& Leeming, 1957 ; Joske \& Blackwell, 1959), however, have reported finding grossly abnormal changes in the jejunal mucosa in a few patients, and these workers considered that latent coeliac disease may have been the aetiological factor. Forshaw (1958) described a patient with post-gastrectomy malabsorption who responded to a gluten-free diet; this was not true, however, of all the cases described by Joske \& Blackwell (1959).

This communication describes two patients with latent gluten enteropathy unmasked by an operation involving a gastro-jejunal anastomosis. In both cases the abnormal jejunal mucosal histology responded to a gluten-free diet.

\section{Case 1}

Mrs D.S., 52 years. In 1959 a gastro-enterostomy operation was performed for a benign prepyloric ulcer. She gave a history as a child of having a tendency to bouts of diarrhoea more frequently than other children and throughout her life she had passed two bowel motions a day. Before operation her haemoglobin was $12.0 \mathrm{~g} / 100 \mathrm{ml}, \mathrm{MCHC} 30 \%$.

After the operation she was unwell for 3 months with diarrhoea and vomiting. Her weight which had been $70 \mathrm{~kg}$ fell to $44.5 \mathrm{~kg}$. During the next 5 years she passed five bowel motions in 24 hours, including one at night. The stool was formed, bulky and offensive, floated on water and was difficult to flush down the toilet. Sheo continued to get bouts of severe diarrhoea and vomiting lasting about 3 days every 3-4 monthse

In 1964 she was admitted for investigation: Her weight was now $38 \mathrm{~kg}$.

On investigation the haemoglobin was $8.2 \mathrm{~g} /$ $100 \mathrm{ml}, \mathrm{MCHC} 26 \%$; red cells showing hypochromia. The bone marrow showed a combination of normoblastic and megaloblastic changes. Serum iron was $29 \mu \mathrm{g} / 100 \mathrm{ml}$; serum vitamin $B_{12} 125 \mathrm{pg} / \mathrm{ml}$ (method of Temperley \& Collery, 1965) ; serum folic acid $1.5 \mathrm{ng} / \mathrm{ml}$ (Temperley \& Horner, 1966) ; blood urea $36 \mathrm{mg} / 100 \mathrm{ml}$; serum proteins, total $5.6 \mathrm{~g} / 100 \mathrm{ml}$, albumin $3.8 \mathrm{~g} / 100$ $\mathrm{ml}$, globulin $1.8 \mathrm{~g} / 100 \mathrm{ml}$, alkaline phosphatase 12 units; serum calcium $9.2 \mathrm{mg} / 100 \mathrm{ml}$ and phosphorus $3.2 \mathrm{mg} / 100 \mathrm{ml}$.

Absorption studies were as follows: faecal fat excretion $29 \mathrm{~g} /$ day, D-xylose and folic acid absorption (Chanarin \& Bennett, 1962) gave maximal blood levels of $9 \mathrm{mg} / 100 \mathrm{ml}$ and $26 \mathrm{ng} / 100 \mathrm{ml}$ respectively. Vitamin $B_{12}$ absorption (Schilling, 1955): $2.1 \%$ excretion in $24 \mathrm{hr}$. Jejunal histology (Fig. 1a) showed flattening and broadening of the villi as well as focal loss of villous pattern. Barium meal and followthrough showed a grossly abnormal small bowel pattern suggesting malabsorption. Treatment with a gluten-free diet was started.

In 1966 her weight had increased to $54 \mathrm{~kg}$ and she was now symptomless. A glucose-galac- 

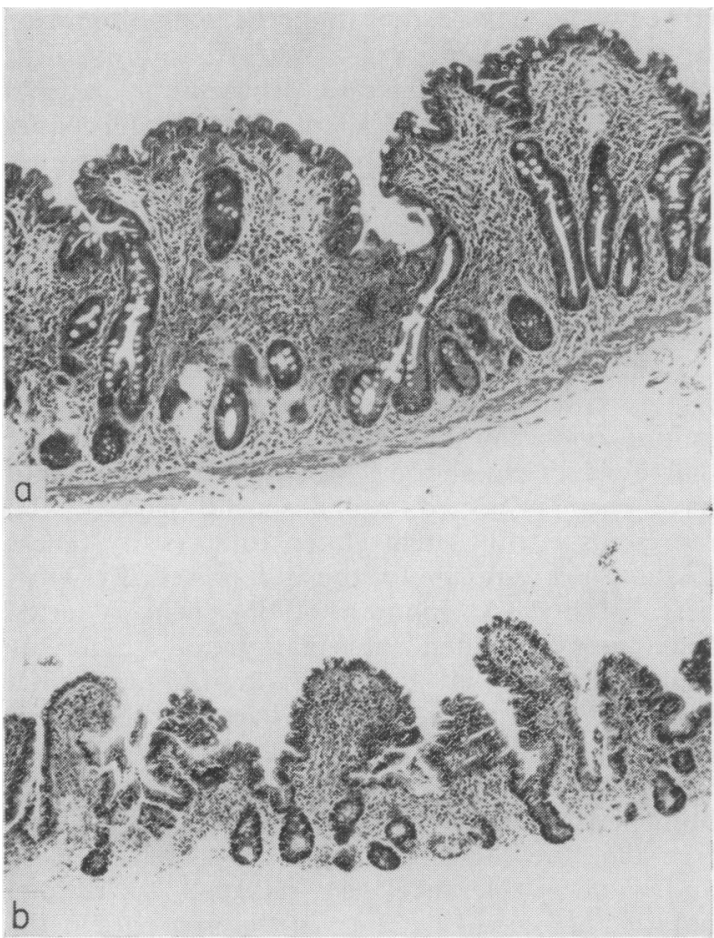

Fig. 1. Jejunal histology in patient D.S. before (a) and after (b) treatment with a gluten-free diet.

tose tolerance curve gave a rise above fasting of $66 \mathrm{mg} / 100 \mathrm{ml}$ whereas lactose, $1 \mathrm{~g} / \mathrm{kg}$ body weight (MacDonald et al., 1966), given both orally and intra-jejunally gave a rise of less than $5 \mathrm{mg} / 100 \mathrm{ml}$ on each occasion. The lactase activity of a repeat jejunal biopsy was zero; although the histology of the villous architecture (Fig. 1b) had greatly improved since 1964.

\section{Case 2}

Mrs S.H., 49 years. From about the age of 19 this patient had complained of bouts of epigastric abdominal pain which had occurred twice a year. She passed one bowel motion daily and had noticed no tendency to attacks of diarrhoea. Cholecystectomy performed in 1957 had brought no relief of symptoms, and in 1961 a Polya partial gastrectomy was performed for a chronic duodenal ulcer. Following the operation she suffered considerable malaise ; her weight which had been $57 \mathrm{~kg}$ fell to $44 \mathrm{~kg}$. Half-an-hour after meals she was prone to syncopal attacks which were associated with marked borborygmi, nausea and colicky abdominal pain which lasted 10-30 min and was followed by severe diarrhoea. She also had nocturnal diarrhoea.

In 1964 in an attempt to relieve her symptoms the gastro-jejunal union was converted to a gastro-duodenal (Billroth I type) anastomosis. During the next 6 months she felt very well. The attacks recurred, however, when she returned to a normal full diet. The diarrhoea was pale, malodorous and frothy.

In 1965 she was admitted for investigation of what was apparently a severe dumping syndrome. Investigations showed haemoglobin $12.0 \mathrm{~g} / 100$ $\mathrm{ml}, \mathrm{MCHC} 33 \%$; the lactose tolerance curve gave a maximum rise of blood sugar above fasting level of $14 \%$ with a glucose-galactose rise of $36 \mathrm{mg} / 100 \mathrm{ml}$. Serum vitamin $B_{12} 550 \mathrm{pg} / \mathrm{ml}$; serum folic acid $2.4 \mathrm{ng} / \mathrm{ml}$.

Absorption tests were as follows: faecal fat excretion was 22 and $25 \mathrm{~g} /$ day (mean of two 3-day collections). Maximum blood level obtained following $\mathrm{D}$-xylose was $22 \mathrm{mg} / 100 \mathrm{ml}$, and folic acid $37 \mathrm{ng} / \mathrm{ml}$. Vitamin $\mathbf{B}_{12}$ absorption $7 \cdot 6 \%$ of dose excreted. The maximal histamine acid output was $1.6 \mathrm{mEq}$. Serum calcium was $10 \cdot 1$ $\mathrm{mg} / 100 \mathrm{ml}$; phosphorus $4.1 \mathrm{mg} / 100 \mathrm{ml}$; and alkaline phosphatase, 6 units. The small bowel pattern following a barium meal showed dilated loops with coarse mucosal folds suggestive of a malabsorption syndrome. Jejunal biopsy (Fig. 2a)

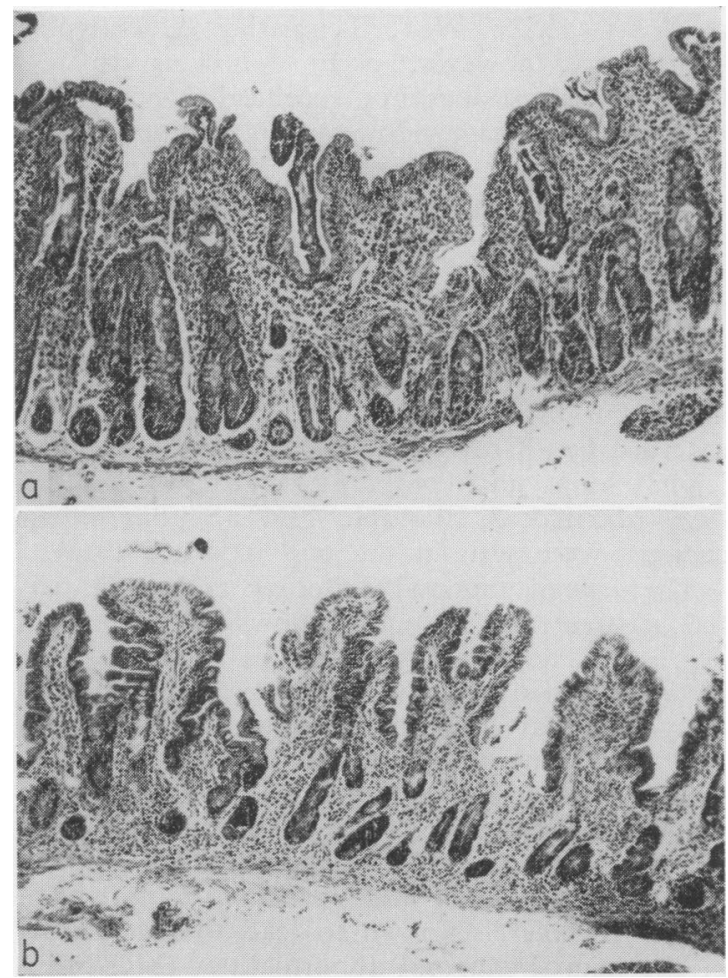

FIG. 2. Jejunal histology in patient S.H. before (a) and after (b) treatment with a gluten-free diet. 
showed jejunal villous atrophy with a mosaic pattern. She was put on a strict gluten-free diet.

In 1966 her weight had increased to $64 \mathrm{~kg}$; the dumping symptoms had abated, but were still present, and she no longer complained of diarrhoea. The histological pattern of the villous structure of a repeat jejunal biopsy (Fig. 2b) while still abnormal showed a considerable improvement on the previous biopsy. Lactose tolerance and mucosal lactase activity were normal.

\section{Discussion}

Both of these patients were acutely ill following an operation involving a gastro-jejunal anastomosis. Each suffered a dramatic drop of 36 and $22 \%$ of her pre-operative weight following a gastro-jejunostomy and Polya gastrectomy, respectively. Anderson, Gunn \& Watt (1955) found that $9.8 \%$ of females lost up to $20 \%$ of body weight following Polya gastrectomy while Cox, Bond \& Podmore (1964) found a loss of $20 \mathrm{~kg}$ in only $2.1 \%$ of patients following a gastrojejunostomy. Malabsorption of fat, D-xylose, folic acid and vitamin $B_{12}$, which characteristically occurs in gluten enteropathy (Hawkins, 1961), was present in both patients. Malabsorption of fat (Wollaeger et al., 1946) and vitamin $\mathrm{B}_{12}$ (Deller \& Witts, 1962; Weir, Temperley \& Gatenby, 1966) may, however, occur following gastrectomy and thus does not specifically incriminate the small intestine. However, malabsorption of D-xylose (Finlay, Hogarth \& Wightman, 1964) and folic acid (Gough, Thirkettle \& Read, 1965) are uncommon following this operation and would suggest that the small intestine was involved.

Following gastro-jejunal anastomosis the upper jejunum may show slight radiological abnormalities but these are localized whereas in gluten enteropathy X-ray changes of dilation of the jejunal loops and coarse mucosal folds are diffuse (Marshak \& Eliasoph, 1957). Similar diffuse changes were seen in the two recorded cases.

The jejunal mucosal histology following partial gastrectomy normally shows only minimal degrees of abnormality (Scott et al., 1964). We have examined the jejunal mucosal histology in forty-eight partial gastrectomy patients (Weir et al., 1962). The two patients recorded here are the only ones who showed severe distortion of villous architecture similar to the findings in gluten enteropathy (Doniach \& Shiner, 1957). Treatment of gluten enteropathy patients with a gluten-free diet is known to lead to reversibility of the jejunal mucosal abnormalities (McDonald et al., 1964). The patients recorded were treated with a gluten-free diet for 26 and 22 months, respectively, before repeating the jejunal biopsy. In both cases there was a marked improvement of the villous architecture. Thus both patients were suffering from a latent gluten enteropathy which was exacerbated by the gastro-jejunal anastomosis. However, this anatomical arrangement, with its resultant perfusion of the flat jejunal mucosa with gastric acid and pepsin, did not prevent the jejunal villous architecture from responding in the normal way to a gluten-free diet.

In the first patient it is conceivable that a mild gluten enteropathy might have been suspected before operation from the history of bouts of diarrhoea in childhood. This, however, could not have been suspected in the second patient who represents a truly latent gluten enteropathy. These findings are similar to those reported by Hedberg, Melnyk \& Johnson (1966), who reported four cases of gluten enteropathy exacerbated by gastric surgery, in three of whom the mucosal histology was markedly improved by a glutenfree diet.

Malabsorption of lactose was demonstrated in both patients. Following treatment with a glutenfree diet the lactase activity of jejunal mucosa and lactose tolerance test returned to normal only in the second patient; in the first patient the lactase activity remained at zero. Both patients avoided taking milk in large quantities but haf5. no trouble from milk puddings and milk addece. to tea. The second patient although physically much improved still has quite severe dumping symptoms which are, therefore, not related to either her gluten enteropathy or initial lactose malabsorption. Welch, Shaw \& Walker (1966) found lactase deficiency following partial gastrectomy in five of twenty-four patients all of whom had a relatively normal jejunal mucosa. However, in twenty-eight post-gastrectomy patients admitted with post-gastrectomy syndromes the two patients described above were the only ones we have found with lactase deficiency (McDonald \& Weir, 1968). The remainder had relatively normal jejunal histology and normal lactase activity. The variation in incidence of lactase deficiency may be due to the geographic variation previously noted by other workers (McMichael, Webb \& Dawson, 1965 ; Cuatrecasas, Lockwood \& Caldwell, 1965).

\section{Acknowledgments}

The author is grateful to Professor P. B. B. Gatenby for his help and advice, Dr D. O'B. Hourihane for reporting on the jejunal biopsies and taking the photographs, Dr G. S. A. McDonald for the lactose tolerance tests and E. Willoughby for the jejunal lactase estimations. 


\section{References}

Anderson, C.D., GunN, R.T.S. \& WATt, J.K. (1955) Results of partial gastrectomy in treatment of peptic ulcer. Brit. med. J. i, 508.

BAIRD, I.M. \& DoDGE, O.G. (1957) Jejunal biopsy after partial gastrectomy. Quart. J. Med. 26, 393.

Chanarin, I. \& Bennett, M. (1962) Absorption of folic acid and D-xylose as tests of small intestinal function. Brit. med. J. i, 985.

Cox, A.G., Bond, M.R. \& Podmore, D.A. (1964) Aspects of nutrition after vagotomy and gastrojejunostomy. Brit. med. J. i, 465.

Cuatrecasas, P., Lockwood, D.H. \& Caldwell, J.R. (1965) Lactase deficiency in the adult. Lancet, $\mathbf{i}, 14$.

Deller, D.J. \& WitTs, L.J. (1962) Changes in the blood after partial gastrectomy with special reference to vitamin B 12 . I. Quart. J. Med. 31, 71.

Doniach, I. \& ShINer, M. (1957) Duodenal and jejunal biopsies. II. Histology. Gastroenterology, 33, 71.

Finlay, J.M., HogarTh, J. \& Wightman, T.J.R. (1964) A clinical evaluation of the D-xylose tolerance test. Ann. intern. Med. 61, 411.

ForsHAw, J.W.B. (1958) Hypoprotemaemia after partial gastrectomy corrected by gluten free diet. Brit. med. J. ii, 1020.

Gough, K.R., Thirkettle, J.L. \& Read, A.E. (1965) Folic acid deficiency in patients after gastric resection. Quart. J. Med. 34, 1 .

Hawkins, C.F. (1961) Idiopathic steatorrhoea. Postgrad. med. J. 37, 761.

HedberG, C.A., MelnyK, C.S. \& Johnson, C.F. (1966) Gluten enteropathy appearing after gastric surgery. Gatroenterology, 50, 796.

Joske, R.A. \& BlACKWEll, J.B. (1959) Alimentary histology in the malabsorption syndrome following partial gastrectomy. Lancet, ii, 379.

Lees, S. \& Grandjean, L.C. (1958) The gastric and jejunal mucosa in healthy patients with partial gastrectomy. Arch. intern. Med. 101, 943.

Marshak, R.H. \& Eliasoph, J. (1957) The roentgen findings in the malabsorption syndrome. Med. Clin. N. Amer. 15, 65.

McDonald, G.S.A., Willoughby, E., Weir, D.G. \& GATENBY, P.B.B. (1966) Milk intolerance in clinical practice. J. Ir. med. Ass. 59, 179.
McDonald, G.S.A. \& WeIR, D.G. (1968) The incidence of lactase deficiency in partial gastrectomy patients. (To be published).

McDonald, W.C., Brandborg, L.L., Flick, A.L., Trier, J.S. \& Rubin, C.E. (1964) Studies of celiac sprue. IV. The response of the whole length of the small bowel to a gluten-free diet. Gastroenterology, 47, 573.

McMichael, H.B., Webb, J. \& Dawson, A.M. (1965) Lactase deficiency in adults. Lancet, i, 717.

Paulley, J.W., Fairweather, F.A. \& Leeming, A. (1957) Postgastrectomy steatorrhoea and patchy jejunal atrophy. Lancet, i, 406.

Schilling, R. F. (1955) The absorption and utilization of vitamin $\mathrm{B}_{12}$. Amer. J. clin. Nutr. 3, 45.

Scott, G.B., Williams, M.J. \& Clark, C.G. (1964) Comparison of jejunal mucosa in postgastrectomy states, idiopathic steatorrhoea, and controls using the dissecting microscope and conventional histological methods. Gut, $5,553$.

ShINER, M. (1959) Small intestinal biopsy: diagnostic and research value. Proc. roy. Soc. Med. 52, 10.

Temperley, I.J. \& Collery, D. (1965) The significance of the serum vitamin $B_{12}$ estimation in clinical practice. Irish J. med. Sci. 317.

TeMPeRley, I.J. \& HoRner, N. (1966) Effect of ascorbic acid on the serum folic acid estimation. J. clin. Path. 19, 43.

Weir, D.G., Temperley, I.J. \& Gatenby, P.B.B. (1963) Anaemia following gastric operations for peptic ulceration in Dublin. II. Irish J. med. Sci. 151.

Weir, D.G., Temperley, I.J. \& Gatenby, P.B.B. (1966) Vitamin $\mathbf{B}_{12}$ deficiency following partial gastrectomy. Irish J. med. Sci. 97.

Welch, J.D., Shaw, R.W. \& WALker, A. (1966) Isolated lactase deficiency producing postgastrectomy milk intolerance. Ann. intern. Med. 64, 1252.

Wollaeger, E.E., Comfort, M.W., Weir, J.F. \& OsterberG, A.E. (1946) The total solids, fat and nitrogen in the feces II. A study of persons who had undergone partial gastrectomy with anastomosis of the entire cut end of the stomach and the jejunum (Polya anastomosis). Gastroenterology, 6, 93. 